\title{
Microbiological treatment of oil mill waste waters
}

\author{
By A. Ranalli \\ Istituto Sperimentale per l'Elaiotecnica. Pescara. ITALIA.
}

RESUMEN

Tratamiento de los alpechines de almazaras con fermentos seleccionados.

Han sido efectuadas pruebas de tratamiento biológico de alpechines, provenientes de sistemas continuos, con fermentos seleccionados adaptados a condiciones de toxicidad muy elevadas.

Han sido utilizadas las formulaciones microbianas SNKD, LLMO y PSBIO; las dos últimas son suspensiones liquidas, constituidas por microorganismos vivos, los cuales a diferencia de los liofilizados o congelados, no deben ser revitalizados antes del uso; estos tienen una fase "lag" más breve y entran antes en completa actividad.

Las pruebas con la preparación biológica SNKD han sido efectuadas en los alpechines filtrados (tipo A) con DQO inicial alrededor de $43 \mathrm{~g} / \mathrm{l}, \mathrm{y}$ también con alpechín filtrado "defenolado" con ácido de Caro $\left(\mathrm{H}_{2} \mathrm{SO}_{5}\right)$ (tipo $\mathrm{B})$, con DQO igual a $30 \mathrm{~g} / \mathrm{l}$; los complexos LLMO y PSBIO se utilizan en alpechines provenientes de la elaboración de otras variedades de aceitunas, filtradas y diluidas en la relación 1:0,5 (tipo $\mathrm{C}$ ) con DQO inicial igual a $44 \mathrm{~g} / \mathrm{l}, \mathrm{y}$ también en alpechín filtrado y sometido previamente a criotratamiento (tipo D), con DQO inicial de $22 \mathrm{~g} / \mathrm{l}$ aproximadamente.

La DQO residual, con la formulación microbiana SNKD, ha resultado igual a $15 \mathrm{~g} / \mathrm{l}$ (Tipo A) y a $5 \mathrm{~g} / \mathrm{l}$ (tipo B), con el PSBIO a $7 \mathrm{~g} / \mathrm{l}$ (tipo C) y a $1,5 \mathrm{~g} / \mathrm{l}$ (tipo D); con la formulación microbiana LLMO a $6 \mathrm{~g} / \mathrm{l}$ (tipo C) y a $1,3 \mathrm{~g} / \mathrm{l}$ (tipo D).

PALABRAS- CLAVE: Alpechín - Fermento seleccionado - Tratamiento biologico.

\section{SUMMARY}

Microbiological treatment of oil mill waste waters.

Experiments of the biological treatment of the oil mill waste waters deriving from continuous system, have been carried out with selected mutant ferments, adapted to rather forced toxic conditions.

The commercial microbic formulations SNKD, LLMO and PSBIO have been utilized; the last two are liquid suspensions, constituted by living micro-organisms that, in contrast to those frozen or lyophilized, do not need be revitalized before their use and became completely active in short time.

The experiments with the SNKD biological preparation were carried out both on filtered oil mill outflows (type A) with an initial COD of approximately $43 \mathrm{~g} / \mathrm{l}$ and on waste water dephenolized by Caro-acid (type B) with a COD equal to $30 \mathrm{~g} / \mathrm{l}$. The experiments with LLMO and PSBIO complexes were conduced both on oil mill outflows filtered and diluted (ratio 1:0.5) with an initial COD equal to $44 \mathrm{~g} / \mathrm{l}$ (type $\mathrm{C}$ ), and on waste water that were filtered and preventatively subjected to a cryogenic treatment (type D), with an initial COD of approximately $22 \mathrm{~g} / 1$.
The residual COD with the microbic formulation SNKD, was about 15 $\mathrm{g} / \mathrm{l}$ (type A) and $5 \mathrm{~g} / \mathrm{l}$ (type B); with the PSBIO it was about $7 \mathrm{~g} / \mathrm{l}$ (type $\mathrm{C}$ ) and $1.5 \mathrm{~g} / \mathrm{l}$ (type D); with the microbic formulation LLMO it resulted in $6 \mathrm{~g} / \mathrm{l}$ (type C) and $1.3 \mathrm{~g} / 1$ (type D). ferment.

KEY-WORDS: Biological treatment - Olive mill wastewater - Selected

\section{INTRODUCTION}

The COD/BOD5 ratio of oil mill waste waters is approximately 2.5 ; this means that the natural microflora is able to remove only a part of the organic material contained in it (Ranalli, 1989).

As it is known the above-mentioned waste waters are characterized by an elevated load of organic substances and by the presence of molecules with a complex structure and that can be degraded with difficulty (Ranalli, 1989).

Some of these substances, as catacolmelaninic pigment (Ranalli, 1987) of phenolic nature, and mostly the free phenols, are moreover strong inhibitors of the biodegrading microflora.

$O$ wing to the quantity, variety, and chemical nature of the organic substances present in the oil mill outflows, their removal by simple or single treatments is not possible and so a multisteps treatment is necessary.

The guidelines for the purification of oil-mill waste water involve, quite often, a biological treatment.

For some years new selected ferments were used for the purification of industrial and civil waste, to improve the efficiency of the biological treatment (Ranalli, 1989).

On this assumptions, experiments of biological treatment by selected microbic formulations, designated SNKD, PSBIO and LLMO and constituted by microbial species adapted to the difficult environmental conditions; were carried out on oil-mill waste waters, opportunely pre-treated to decrease the organic load and the amount of the inhibitory substances. 


\section{MATERIALS AND METHODS}

The SNKD complex is constituted by 83 microbic species, related to the genres: Saccharomyces, Bacillus, Candida, Endomycopsis, Cladosporium, Nocardia, Streptomyces, Clostridium, Azotomonas, Pseudomonas, Bacterium, and Basidiomycetes.

The biological components of the PSBIO includes selected living organisms, in liquid suspension, related to the following families: Rhodospirillaceae, Rhodopseudomonas, Chromatiaceae, Thiosarcina, Thiospirillum, Lamprocistys, Ectothiorhodospira, Amoebobacter, Chloropseudomonas, Clathrochloris, Chlorobaceae.

The biological preparation LLMO (Liquid Live Micro Organisms) contains 7 microbic species, 5 of which are aerobic (Aerobacter aerogenes, Bacillus subtilis, Nitrobacter winogradskyi, Pseudomonas stutzeri, Pseudomonas denitrificans) and 2 anaerobic (Cellulomonas biazotea and Rhodopseudomonas palustris).

The experiments were conducted in aerobic environment (Ranalli, 1988).

The waste water utilized came from continuous extraction systems and was pre-treated in various ways, obtaining 4 types of effluents that were different as regards the initial organic material amount and inhibitory substances concentration, and indicated by the letters $A$, B, C, D.

The experiments with the SNKD biological preparation were carried out both on filtered waste water (type A) with an initial COD of approximately $43 \mathrm{~g} / \mathrm{l}$ and on waste water de-phenolized by Caro-acid $\left(\mathrm{H}_{2} \mathrm{SO}_{5}\right)$ with a COD equal to $30 \mathrm{~g} / \mathrm{l}$ (type $\mathrm{B}$ ). The experiments with LLMO and PSBIO complexes were conducted both on waste water deriving from the culture of other varieties of olives (type C), filtered and diluted (ratio 1:0,5) with an initial COD equal to $44 \mathrm{~g} / \mathrm{l}$, and on waste water that were filtered and preventatively subjected to a cryogenic treatment (type D), with an initial COD of approximately $22 \mathrm{~g} / \mathrm{l}$.

For each of 4 types of effluent a control (not inoculated) was provided.

Each test was carried out, in triplicate, using $750 \mathrm{ml}$ of waste water in 1 liter Erlenmeyer flasks in wich air was bubbled during the experiment $(50 \mathrm{l} / \mathrm{h})$.

Before the inoculation the concentration of $\mathrm{C}, \mathrm{N}$ and $\mathrm{P}$ was adjusted at corrected ratio $100: 16: 1$ to provide the best growth of the microorganisms.

The $\mathrm{pH}$ of the waste waters was brought to the approximate level of 7 and corrections undertaken every day to mantain such value. $30^{\circ} \mathrm{C}$.

The temperature of the waste water was regulated at

The lyophilized ferments were revitalized before their use (2).

On the waters, at the beginning, during, and at the end of the digestive process, the following parameters were determined: $C O D$, total solids at $105^{\circ} \mathrm{C}$, total solids at $180^{\circ} \mathrm{C}$, volatile solids, reducing sugars, phenols and fats.
The analytical observations were carried out on the centrifugated liquid.

\section{RESULTS AND DISCUSSIONS}

The following are the mean percentage data concerning the final rate of removal of the single analytical parameters, attained by the microbic formulations under consideration, on the 4 types of waste water. The trend of the average variations during the digestive process of the single parameters $\left(C O D\right.$, total solids at $105^{\circ} \mathrm{C}$, reducing sugars) is visualized in figures $1,2,3,4,5$ and 6 . The residual absolute values of those parameters are summarized in Table I.

COD (initial values: $A=42.8 \mathrm{~g} / \mathrm{l}, \mathrm{B}=29.6 \mathrm{~g} / \mathrm{l}, \mathrm{C}=43.6$ $\mathrm{g} / \mathrm{l}, \mathrm{D}=21.6 \mathrm{~g} / \mathrm{l})$.

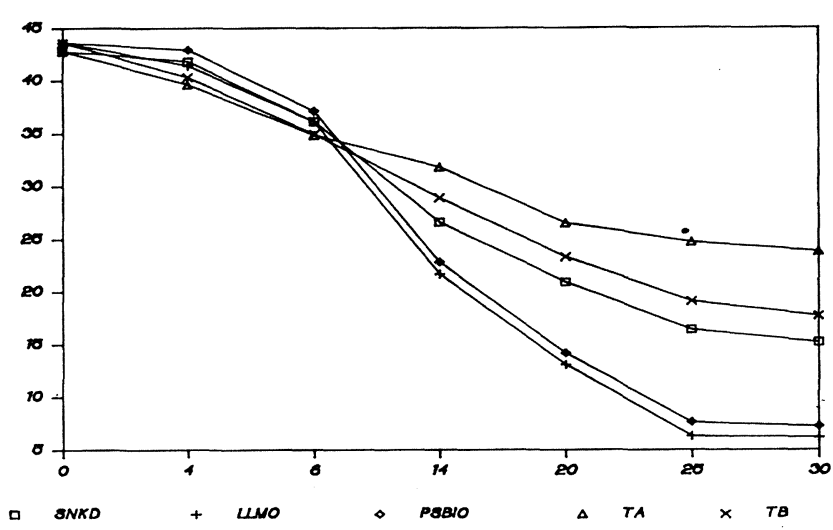

Figure 1

Time course (days) for the mean variations of the COD $(g / l)$

$\mathrm{TA}=$ control type $\mathrm{A}$ waste water (inoculated with SNKD biological complex).

$\mathrm{TC}=$ control type $\mathrm{C}$ waste water (inoculated with LLMO and PSBIO microbial formulations).

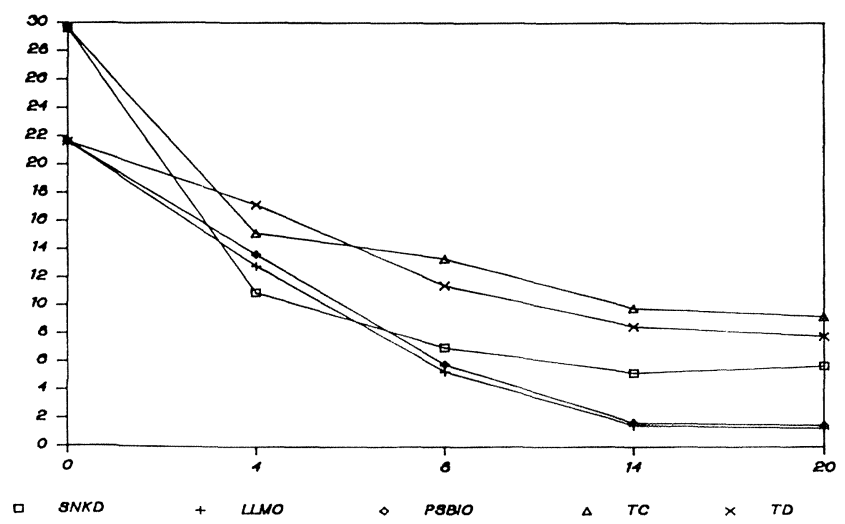

Figure 2

Time course (days) for the mean variations of the $C O D(g / l)$. $\mathrm{TB}=$ control type $\mathrm{B}$ waste water (inoculated with SNKD biological complex).

$T D=$ control type $D$ waste water (inoculated with LLMO and PSBIO microbial formulations). 


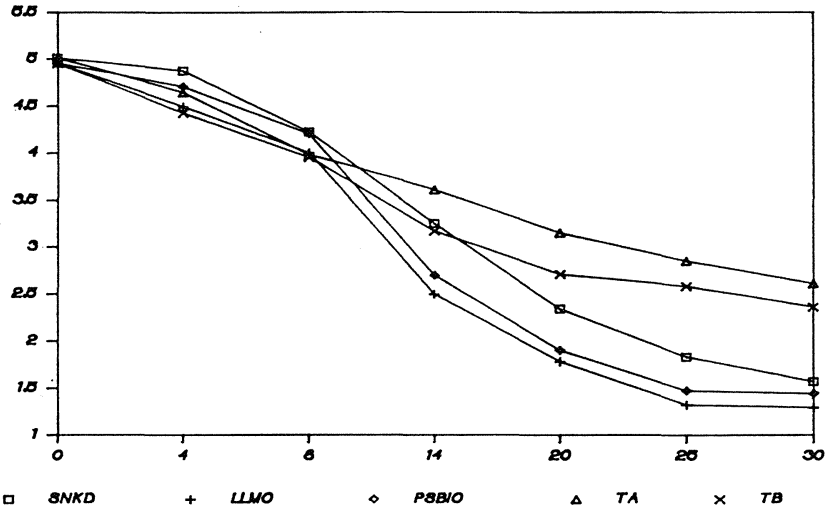

Figure 3

Time course (days) for the mean variations of the total solids $\left(105^{\circ} \mathrm{C}\right) \%$ $\mathrm{TA}=$ control type $A$ waste water (inoculated with SNKD biological complex).

$\mathrm{TC}=$ control type $\mathrm{C}$ waste water (inoculated with LLMO and PSBIO microbial formulations).

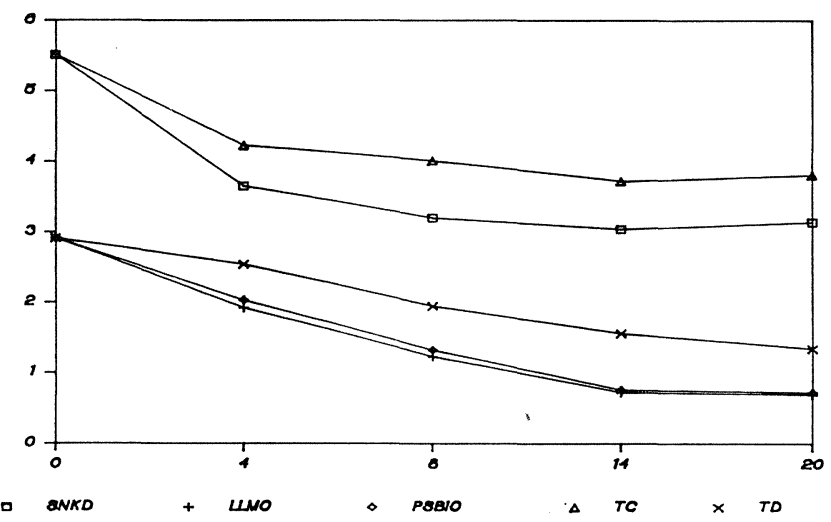

Figure 4

Time course (days) for the mean variations of the total solids $\left(105^{\circ} \mathrm{C}\right) \%$.

$\mathrm{TB}=$ control type $\mathrm{B}$ waste water (inoculated with SNKD biological complex).

$\mathrm{TD}=$ control type $\mathrm{D}$ waste water (inoculated with LLMO and PSBIO microbial formulations).

Taking into account the type $A$ waste water inoculated with the microbic formulation SNKD, the removal percentage of the COD at date of the last sampling, i.e., after 33 days, is $66.5 \%$ and for the control $44.4 \%$; as regards the type B waste water inoculated with the microbic complex SNKD, the removal percentage of COD, after 14 days, beyond wich variations are no longer statistically significant (Tukey test, $P \leq 0.05$ ) was equal to $82.4 \%$ against the $66.9 \%$ of the control; on type C waste water, inoculated with the microbic formulation LLMO, the removal percentage of the parameter, after 30 days, corresponds to $85.8 \%$ and for the control 59.4\%; as regards type $C$ waste water treated by the microbic system PSBIO, the removal percentage of the COD, after 30 days, was $83.5 \%$ and for the control $59.4 \%$; as regards the type $D$ waste water inoculated with the LLMO formulation, the removal percentage of COD, after 14 days, was $93.1 \%$ against the

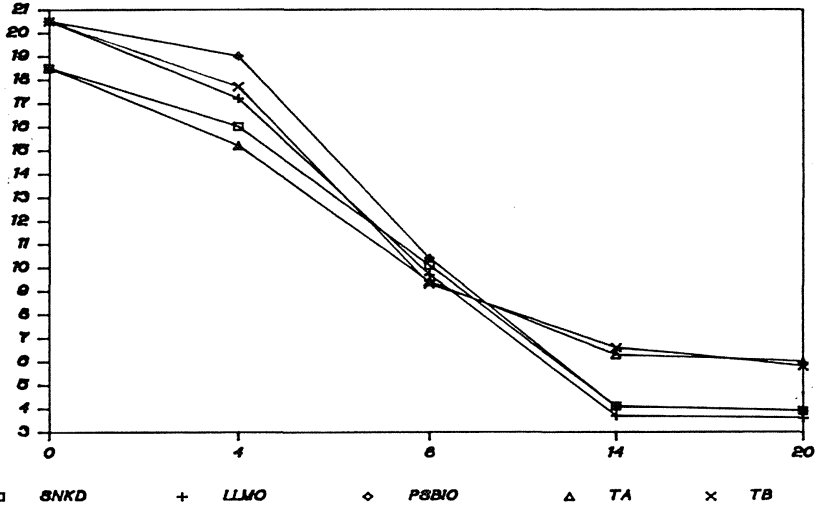

Figure 5

Time course (days) for the mean variations of the reducing sugars ( $g$ / 1).TA= control type $A$ waste water (inoculated with SNKD biological complex).

$\mathrm{TC}=$ control type $\mathrm{C}$ waste water (inoculated with LLMO and PSBIO microbial formulations).

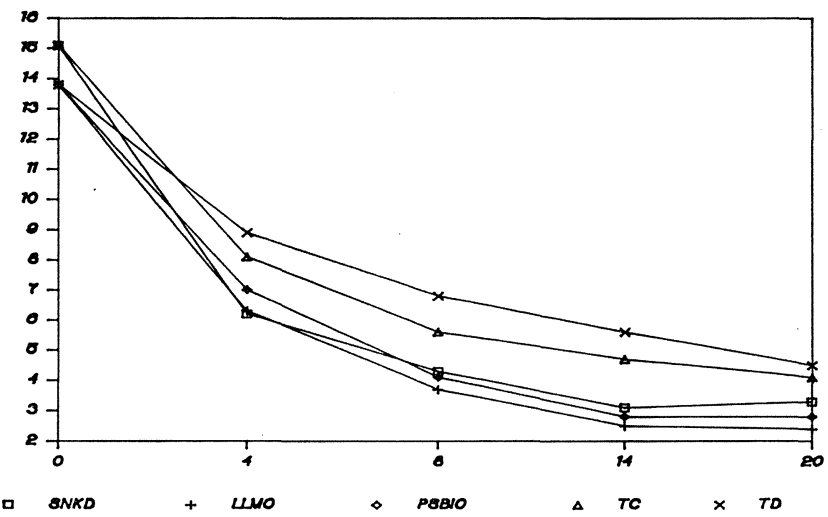

Figure 6

Time course (days) for the mean variations of the reducing sugars ( $g$ / 1).TB $=$ control type $\mathrm{B}$ waste water (inoculated with SNKD biological complex).

$\mathrm{TC}=$ control type $\mathrm{C}$ waste water (inoculated with LLMO and PSBIO microbial formulations).

$60.6 \%$ of the control; as regards the type D waste water, treated by the biological preparation $\mathrm{PSBIO}$, the removal percentage of the COD, after 14 days, was $92.1 \%$ against the $63.9 \%$ of the control.

- TOTAL SOLIDS AT $105^{\circ} \mathrm{C}$ (initial values: $A=5.01 \%$, $B=5.51 \%, C=4.95 \%, D=2.91 \%$ ).

By SNKD microbic complex the removal percentage of this parameter in type $A$ waste water, after 30 days, was $68.7 \%$ (control $47.9 \%$ ) and in type B, after 20 days, $43.0 \%$ (control $30.9 \%$ ); by LLMO bacteria, in type $\mathrm{C}$ waste water, it was $73.9 \%$ (control $53.2 \%$ ) and in type $D$, after 14 days, $75.3 \%$ (control $46.4 \%$ ); by PSBIO microbic formulation, in type C waste water, it was $70.9 \%$ (control $52.8 \%$ ) and in type D $73.8 \%$ (control $46.4 \%$ ).

VOLATILE SOLIDS (initial values: $\mathrm{C}=4.17 \%, \mathrm{D}=$ $2.09 \%)$ 
Table I

Mean residual values of the analytical parameters in the oil-mill waste waters.

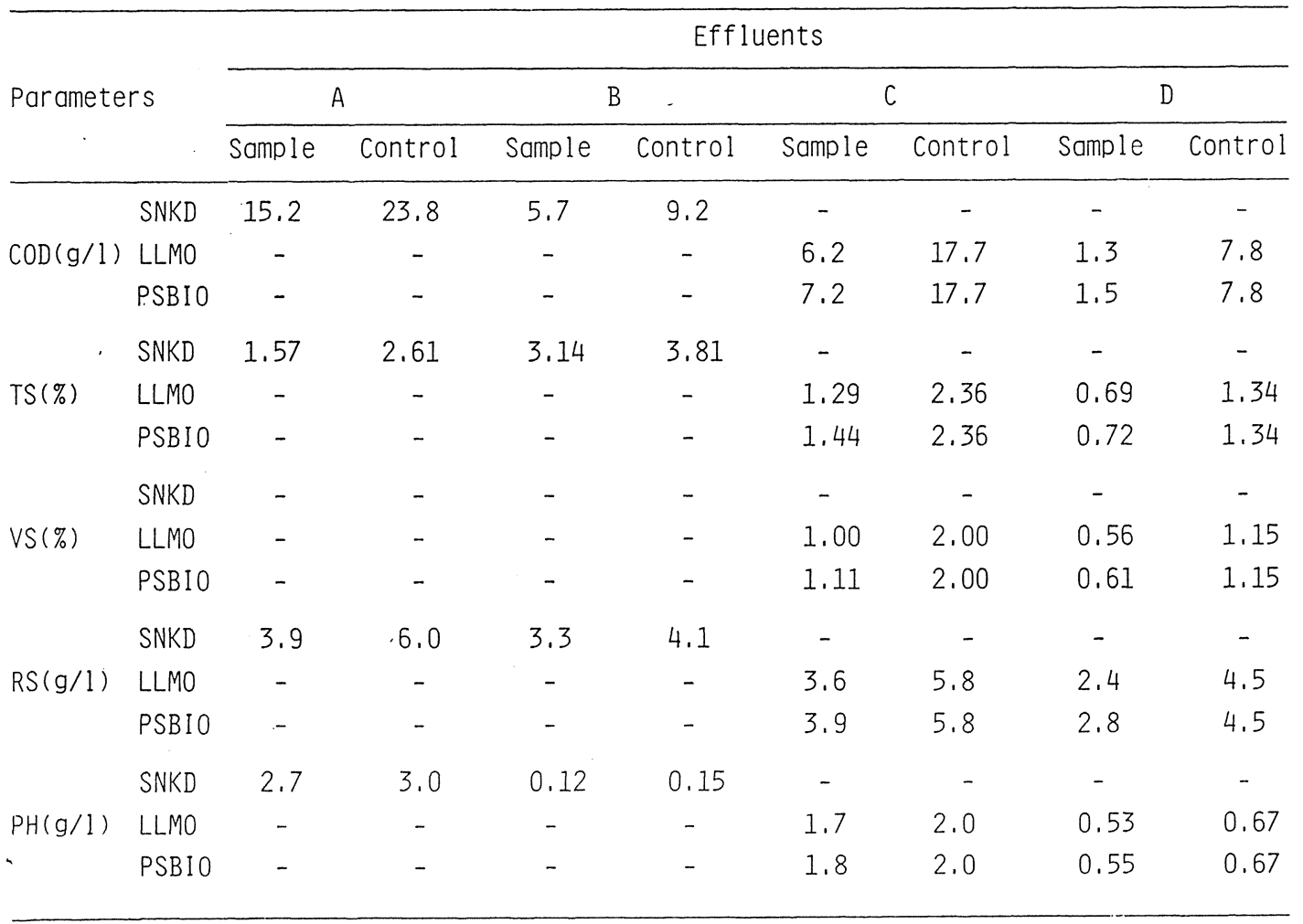

By the LLMO bacteria the removal percentage of this parameter, in type $\mathrm{C}$ waste water, after 30 days, was $76.0 \%$ (control $52.0 \%$ ) and in type D, after 14 days, it was $70.3 \%$ (control $32.5 \%$ ); by PSBIO microbic formulation, in type C waste water, it was $73.4 \%$ (control $52.0 \%$ ) and in type D $68.4 \%$ (control $32.5 \%$ ).

REDUCING SUGARS (initial values: $A=18.5 \mathrm{~g} / \mathrm{l}, \mathrm{B}=$ $15.1 \mathrm{~g} / \mathrm{l}, \mathrm{C}=20.5 \mathrm{~g} / \mathrm{l}, \mathrm{D}=13.8 \mathrm{~g} / \mathrm{l})$.

By SNKD biological complex the removal percentage of this parameter, in type A waste water, after 14 days, was $77.8 \%$ (control $65.9 \%$ ) and in type B $79.5 \%$ (control $68.9 \%$ ); by LLMO microbic formulation, in type D waste water, it was $82.0 \%$ (control $67.8 \%$ ) and in type D $81.9 \%$ (control $59.4 \%$ ); by PSBIO microbic formulation, in type C waste water, it was $80.0 \%$ (control $67.8 \%$ ) and in type D $79.7 \%$ (control $59.4 \%$ ).

PHENOLS (initial values: $A=3.6 \mathrm{~g} / \mathrm{l}, \mathrm{B}=178 \mathrm{mg} / \mathrm{l}, \mathrm{C}=$ $2.5 \mathrm{~g} / \mathrm{l}, \mathrm{D}=862 \mathrm{mg} / \mathrm{l})$

By SNKD biological complex the removal percentage of this parameter, in type A waste water, after 20 days, was $25.0 \%$ (control $16.7 \%$ ) and in type B $32.6 \%$ (control $16.9 \%$ ); by LLMO bacteria, in type C waste water, it was $32.0 \%$ (control $20.0 \%$ ) and in type D $35.6 \%$ (control $20.1 \%$ ); by PSBIO microbic formulation, in type C waste water, it was $28.0 \%$ (control $20.0 \%$ ) and in type D $35.3 \%$ (control $20.1 \%$ ).

For the sake of brevity, the data relative to the level of removal of fat (oil) are omitted; the fat, was in any case, largely separated by preventatively operation of filtration.

The oil mill waste waters could be treated in higher quantity in conjunction with urban liquid wastes in activitated sludge plants after removal of a significant \% of organic loads by means of previous treatment with one of the above-reported microbial formulations (Mascolo and Cucurachi, 1981). As alternative, the pretreated liquid wastes may be applied on the agricultural soils, but it is necessary its diluition to reduce further its contained in organic and inorganic substances.

\section{ACKNOWLEDGEMENTS}

My thanks go to the Ecoil Society of Ravenna for providing free samples of the SNKD, LLMO and PSBIO biological preparations.

\section{REFERENCES}

1. Ranalli (1987) -»Influenza del pigmento catecolmelanico sul carico inquinante dei reflui di frantoion.- Inquinamento $X X \mid X, 40-43$.

2. Ranalli, A. (1988) -»Ricerche sull'impiego dei fermenti selezionati nel trattamento biologico delle acque reflue dei frantoi. Nota preliminaren.Riv. Ital. Sostanze Grasse LXV, 529-533.

3. Ranalli, A. (1989) -"Schemi di trattamento e utilizzazione delle acque reflue della lavorazione delle olive".- Imbottigliamento 12, 78-87.

4. Ranalli, A. (1989) - -Il problema dei reflui di frantoio. Aspetti tecnici e normativi."- L'infor. Agrario 45, 29-52.

5. Mascolo, A.e Ltri. (1989). - "Lo smaltimento delle acque di vegetazione delle olive negli impianti a fanghi attivi destinati alla depurazione dei liquami urbani".- Ann. Istit. Sperimentale Elaiotecnica $\mathbf{X}$.

(Recibido: Abril 1991) 